\title{
Insulin response to intravenous glucagon in children with familial constitutional short stature
}

\author{
MOSHE KARP, ZVI LARON, and MICHAEL DORON \\ From the Institute of Paediatric and Adolescent Endocrinology, Beilinson Medical Centre, Petach Tikva, \\ and the Sackler School of Medicine, Tel Aviv University, Israel
}

\begin{abstract}
Karp, M., Laron, Z., and Doron, M. (1975). Archives of Disease in Childhood, 50,805 . Insulin response to intravenous glucagon in children with familial constitutional short stature. An intravenous glucagon test was performed in 8 children with familial constitutional short stature who were also lean. These children were randomly selected from a larger group of children with the same clinical manifestation and who had been shown to have a low insulin response to an oral glucose tolerance test and to an intravenous arginine test, without glucose intolerance. 7 out of 8 children showed a normal insulin response to intravenous glucagon, with a peak level of $53-180 \mu \mathrm{U} / \mathrm{ml} 2$ minutes after the injection.

It is assumed that these insulin responses represent an intact 'rapid' pool of insulin within the $\beta$-cell, and can explain the absence of glucose intolerance in all the children so far studied.
\end{abstract}

Karp, Laron, and Doron (1973) described a group of 36 children with familial short stature who showed the following common features. Height was below the 3 rd centile, skeletal age was retarded by 2 or more years, and they were lean (subcutaneous skinfold thickness of $5 \mathrm{~mm}$ or less). The distinct biochemical abnormalities were abnormally low insulin responses to intravenous arginine and to oral glucose in the presence of a normal growth hormone response. Despite the low insulin, no glucose intolerance was present. It was suggested that the low insulin secretion may have been related to the leanness of the body, and may have led to their reduced growth rate and slow skeletal maturation (Laron et al., 1972).

The present investigation was designed to clarify the ability of these patients to secrete insulin, by measuring plasma insulin response after a single bolus intravenous injection of glucagon.

\section{Subjects and methods}

A total of 8 subjects were investigated, 7 males and 1 female (Table I). They were selected randomly from 36 subjects studied previously. The age range was 6 years 3 months -12 years 5 months. All were short, their height being $-2 \cdot 4 \mathrm{SD}$ to $-4 \cdot 2 \mathrm{SD}$ below the mean according to the tables of Tanner, Whitehouse, and Takaishi (1966). Most Jewish ethnic groups fall

Received 13 February 1975. within the normal limits of these charts (Laron, 1968). All subjects were lean, with a subscapular skinfold thickness of $5 \mathrm{~mm}$ or less. 7 were of oriental Jewish origin.

All tests were performed on an ambulatory basis after an overnight (12- to 14-hour) fast. Before the tests all the subjects were given their regular diet, which contained at least $250 \mathrm{~g}$ carbohydrates per day. An indwelling needle was inserted into the antecubital vein and the patient then rested in a recumbent position for one hour before the start of the test. The intravenous glucagon test was performed by injecting crystalline glucagon (Eli Lilly \& Co.) $0.03 \mathrm{mg} / \mathrm{kg}$ rapidly in 2 to 4 seconds. Blood was withdrawn for glucose, insulin, and growth hormone at $0,2,5,10,20,30,40,50,60,90$, and 120 minutes. Blood glucose was determined on the day of the test with the Technicon Autoanalyser. Plasma insulin was assayed by a double-antibody radioimmunoassay using a modification of the method of Hales and Randle (1963). Plasma growth hormone was assayed by radioimmunoassay using a charcoal modification of a previously described method (Laron and Mannheimer, 1966). Control values for each test were obtained by examination of endocrine healthy, nonobese childíen and adolescents.

\section{Results}

Table II summarizes the effect of the intravenous injection of glucagon. Fasting blood sugar ranged between 76 and $97 \mathrm{mg} / 100 \mathrm{ml}$; a slight rise was seen after 5 minutes and a peak ranging from 110 
TABLE I

Pertinent clinical data of 8 children with familial constitutional short stature

\begin{tabular}{|c|c|c|c|c|c|c|}
\hline \multirow{2}{*}{$\begin{array}{c}\text { Case } \\
\text { no. }\end{array}$} & \multirow{2}{*}{ Sex } & \multirow{2}{*}{$\underset{(y r)}{\text { Age }}$} & \multirow{2}{*}{$\begin{array}{c}\text { Height } \\
\text { (SD) }\end{array}$} & \multicolumn{2}{|c|}{ Skinfold (mm) } & \multirow{2}{*}{$\begin{array}{l}\text { Country of } \\
\text { origin of } \\
\text { father }\end{array}$} \\
\hline & & & & Iliac & Subscapular & \\
\hline $\begin{array}{l}1 \\
2 \\
3 \\
4 \\
5 \\
6 \\
7 \\
8\end{array}$ & $\begin{array}{l}\mathrm{M} \\
\mathrm{M} \\
\mathrm{M} \\
\mathrm{M} \\
\mathrm{M} \\
\mathrm{M} \\
\mathrm{M} \\
\mathrm{F}\end{array}$ & $\begin{array}{rl}12 & 5 \\
9 & 5 \\
8 & 9 \\
6 & 3 \\
11 & 5 \\
9 & 3 \\
8 & 6 \\
9 & 1\end{array}$ & $\begin{array}{l}-2 \cdot 4 \\
-3 \cdot 1 \\
-4 \cdot 2 \\
-3 \cdot 3 \\
-2 \cdot 9 \\
-3 \cdot 1 \\
-2 \cdot 5 \\
-3 \cdot 3\end{array}$ & $\begin{array}{l}5 \\
5 \\
3 \\
3 \\
5 \\
4 \\
5 \\
5\end{array}$ & $\begin{array}{l}3 \\
5 \\
3 \\
4 \\
6 \\
4 \\
5 \\
6\end{array}$ & $\begin{array}{l}\text { Morocco } \\
\text { Iraq } \\
\text { Yemen } \\
\text { Yemen } \\
\text { Morocco } \\
\text { Yemen } \\
\text { Israel } \\
\text { Morocco }\end{array}$ \\
\hline
\end{tabular}

to $167 \mathrm{mg} / 100 \mathrm{ml}$ occurred after 20 to 40 minutes. However, plasma insulin rose rapidly from the low fasting levels. In 7 out of the 8 children a significant peak (54 to $180 \mu \mathrm{U} / \mathrm{ml}$ ) was observed at 2 minutes after the injection, slowl decreasing thereafter to starting values between 30 and 60 minutes. Only one subject (Case 4) had a low $(36 \mu \mathrm{U} / \mathrm{ml})$ and delayed $(60 \mathrm{~min})$ insulin peak.

With the exception of Case 5, all had low to normal plasma growth hormone concentrations at the start of the test. The peak time occurred between 20 and 40 minutes in 5 children, and was delayed $(120 \mathrm{~min})$ in 2 . In Case 5 who had a high fasting value, a plateau was reached, followed by a decrease to normal values between 50 and 60 minutes followed by a second peak at 120 minutes.

Table III shows a comparison of the peak insulin levels obtained in the previous study during intravenous arginine, oral glucose tolerance test, and intravenous glucose tolerance test (IVGTT) with the results from the present study. With one exception the overall insulin response to intravenous glucagon was greater than the insulin response obtained during arginine infusion, and during oral or intravenous glucose tolerance. When compared to the peak in IVGTT at 2 minutes, the insulin peak during intravenous glucagon was higher in 5 patients, the same in 1 and lower in 1. The Fig. shows the comparative response in 3 children (Cases $2,6,8$, respectively).

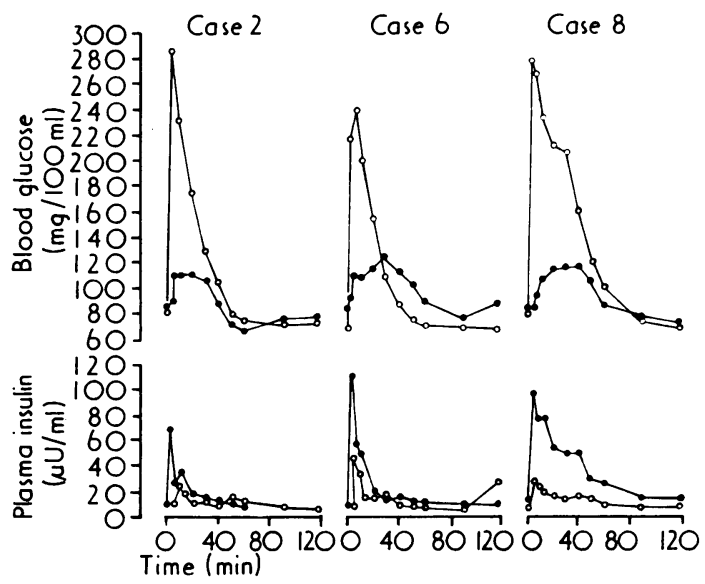

Fig.-Glucose and insulin response to intravenous glucose $(O)$ and intravenous glucagon $(0)$ in 3 cases $(2,6,8)$ with familial constitutional short stature.

Blood glucose, plasma insulin, and growth hormone responses to intravegnc

\begin{tabular}{|c|c|c|c|c|c|c|c|c|c|c|c|c|c|c|c|c|}
\hline \multirow{3}{*}{$\begin{array}{c}\text { Case } \\
\text { no. }\end{array}$} & \multicolumn{11}{|c|}{ Blood glucose $(\mathrm{mg} / 100 \mathrm{ml})$} & \multicolumn{5}{|c|}{ Plasma $\overline{\text { ins }}$} \\
\hline & \multicolumn{11}{|c|}{ Minutes } & & & & & \\
\hline & 0 & 2 & 5 & 10 & 20 & 30 & 40 & 50 & 60 & 90 & 120 & 0 & 2 & 5 & 10 & \\
\hline 1 & 90 & 92 & 96 & 109 & 129 & 137 & 124 & 105 & 97 & 90 & 91 & 11 & 180 & 101 & 60 & 38 \\
\hline 2 & 84 & 88 & 108 & 108 & 110 & 106 & 86 & 70 & 64 & 78 & 76 & 8 & 67 & 25 & 34 & $1 \%$ \\
\hline 3 & 76 & 88 & 94 & 106 & 110 & 116 & 104 & 96 & 82 & 80 & 82 & 8 & 57 & 35 & 20 & 12 \\
\hline 4 & 97 & 97 & 103 & 115 & 129 & 149 & 167 & 167 & - & 133 & 86 & 4 & 6 & 9 & 16 & 18 \\
\hline 5 & 83 & 86 & 103 & 119 & 130 & 120 & 120 & 102 & 93 & 76 & 80 & 7 & 54 & 40 & 38 & 109 \\
\hline 6 & 82 & 88 & 106 & 106 & 114 & 122 & 111 & 100 & 87 & 75 & 85 & 8 & 108 & 55 & 48 & 19 \\
\hline 7 & 90 & 90 & 102 & 110 & 116 & 115 & 94 & 64 & 74 & 64 & 71 & 8 & 53 & 34 & - & 17 \\
\hline 8 & 81 & 81 & 90 & 104 & 112 & 113 & 114 & 103 & 82 & 76 & 72 & 13 & 94 & 74 & 75 & \\
\hline
\end{tabular}


TABLE III

Comparison between peak plasma insulin levels during intravenous arginine, oral glucose tolerance test (GTT), intravenous glucose, and intravenous glucagon in children with familial constitutional short stature

\begin{tabular}{|c|c|c|c|c|}
\hline \multirow{2}{*}{$\begin{array}{c}\text { Case } \\
\text { no. }\end{array}$} & \multicolumn{4}{|c|}{ Peak insulin $(\mu \mathrm{U} / \mathrm{ml})$} \\
\hline & Arginine & Oral GTT & GTT* $^{\star}$ & Glucagon* \\
\hline $\begin{array}{l}1 \\
2 \\
3 \\
4 \\
5 \\
6 \\
7 \\
8\end{array}$ & $\begin{array}{l}15 \\
25 \\
11 \\
10 \\
16 \\
22 \\
18 \\
23\end{array}$ & $\begin{array}{l}41 \\
34 \\
23 \\
20 \\
27 \\
19 \\
45 \\
30\end{array}$ & $\begin{array}{l}11 \\
26 \\
54 \\
59 \\
42 \\
45 \\
\frac{28}{2}\end{array}$ & $\begin{array}{r}180 \\
67 \\
57 \\
36 \\
54 \\
108 \\
53 \\
94\end{array}$ \\
\hline $\begin{array}{l}\text { Normal children } \\
\text { and adolescents } \\
\text { (mean } \pm \text { SD) }\end{array}$ & $\begin{array}{l}n=41 \\
56 \pm 47\end{array}$ & $\begin{array}{l}n=53 \\
101 \pm 60\end{array}$ & $\begin{array}{l}n=6 \\
60 \pm 15\end{array}$ & $\begin{array}{l}n=14 \\
88 \pm 58\end{array}$ \\
\hline
\end{tabular}

ॠAt 2 minutes, except Case 2 where at 5 minutes.

\section{Discussion}

In contradistinction to the low insulin response to arginine and the oral glucose tolerance test in children with familial constitutional short stature, bone age retardation, and lean body, we found a normal insulin response to intravenous glucagon in 7 out of 8 children tested. When comparing these responses with the insulin rise at 2 minutes during an IVGTT, it was found that only 2 children (Cases 3 and 4) had a normal insulin response, 2 (Cases 5 and 6 ) had a relatively low response and 3 (Cases 1,2 and 8) a markedly low insulin response; thus showing the marked difference between the stimulation of the $\beta$-cells of these patients with glucagon on the one hand, and with glucose (oral or IV) on the other. The difference was further proven when comparing the glucose concentrations to the concomitant insulin response. It was clearly seen (Fig.), that the insulin response is not related to the level of blood glucose, which was much higher after the glucose injection than after the glucagon injection. Glucagon injection induces a rapid insulin response in healthy subjects (Samols, Marri, and Marks, 1965) probably by a direct stimulation of the pancreas (Devrim and Recant, 1966). This was further corroborated from the present study.

Further evidence for a different mechanism of action of glucose and glucagon on the $\beta$-cell is that in diabetic children requiring exogenous insulin it was shown that intravenous glucagon can elicit a positive insulin response which is, however, shorter and lower than in controls (Chiumello, Del Guercio, and Bidone, 1968; Weber, 1975).

The low insulin response to oral GTT in the children we studied was in the range observed in our clinic in children with juvenile type diabetes.

The main difference was the absence of glucose

ucagon $(0.03 \mathrm{mg} / \mathrm{kg})$ in children with familial constitutional short stature

\begin{tabular}{|c|c|c|c|c|c|c|c|c|c|c|c|c|c|c|}
\hline \multicolumn{4}{|l|}{$\mathrm{J} / \mathrm{ml}$ ) } & \multicolumn{11}{|c|}{ Plasma growth hormone (ng/ml) } \\
\hline \multirow[b]{2}{*}{50} & \multirow[b]{2}{*}{60} & \multirow[b]{2}{*}{90} & \multirow[b]{2}{*}{120} & \multicolumn{11}{|c|}{ Minutes } \\
\hline & & & & 0 & 2 & 5 & 10 & 20 & 30 & 40 & 50 & 60 & 90 & 120 \\
\hline $\begin{array}{r}18 \\
7 \\
9 \\
26 \\
10 \\
10 \\
7 \\
27\end{array}$ & $\begin{array}{r}14 \\
5 \\
6 \\
36 \\
9 \\
9 \\
9 \\
22\end{array}$ & $\begin{array}{r}10 \\
8 \\
19 \\
6 \\
7 \\
9 \\
11\end{array}$ & $\begin{array}{r}10 \\
8 \\
5 \\
5 \\
8 \\
6 \\
12\end{array}$ & $\begin{array}{r}7 \cdot 1 \\
1 \cdot 0 \\
1 \cdot 0 \\
1 \cdot 1 \\
20 \cdot 9 \\
2 \cdot 4 \\
3 \cdot 3 \\
2 \cdot 7\end{array}$ & $\begin{array}{r}4 \cdot 0 \\
1 \cdot 0 \\
1 \cdot 0 \\
5 \cdot 5 \\
21 \cdot 1 \\
2 \cdot 2 \\
7 \cdot 9 \\
2 \cdot 2\end{array}$ & $\begin{array}{r}3 \cdot 4 \\
1 \cdot 3 \\
2 \cdot 0 \\
6 \cdot 3 \\
21 \cdot 9 \\
1 \cdot 9 \\
12 \cdot 1 \\
2 \cdot 2\end{array}$ & $\begin{array}{r}3 \cdot 8 \\
7 \cdot 4 \\
5 \cdot 2 \\
9 \cdot 5 \\
17 \cdot 9 \\
3 \cdot 7 \\
13 \cdot 3 \\
2 \cdot 4\end{array}$ & $\begin{array}{r}2 \cdot 3 \\
14 \cdot 0 \\
9 \cdot 0 \\
11 \cdot 3 \\
16 \cdot 9 \\
6 \cdot 4 \\
15 \cdot 2 \\
1 \cdot 8\end{array}$ & $\begin{array}{r}1 \cdot 4 \\
13 \cdot 0 \\
8 \cdot 7 \\
8 \cdot 3 \\
10 \cdot 9 \\
10 \cdot 1 \\
12 \cdot 0 \\
1 \cdot 0\end{array}$ & $\begin{array}{r}1 \cdot 4 \\
13 \cdot 0 \\
7 \cdot 3 \\
4 \cdot 6 \\
7 \cdot 3 \\
11 \cdot 8 \\
6 \cdot 8 \\
1 \cdot 1\end{array}$ & $4 \cdot 5$ & $\begin{array}{r}1 \cdot 0 \\
5 \cdot 5 \\
3 \cdot 0 \\
2 \cdot 3 \\
3 \cdot 8 \\
11 \cdot 1 \\
3 \cdot 1 \\
1 \cdot 6\end{array}$ & $\begin{array}{r}18 \cdot 9 \\
3 \cdot 0 \\
1 \cdot 0 \\
1 \cdot 8 \\
13 \cdot 1 \\
4 \cdot 9 \\
1 \cdot 7 \\
1 \cdot 5\end{array}$ & $\begin{array}{r}17 \cdot 8 \\
13 \cdot 4 \\
1 \cdot 4 \\
1 \cdot 0 \\
13 \cdot 3 \\
2 \cdot 0 \\
6 \cdot 1 \\
13 \cdot 2\end{array}$ \\
\hline
\end{tabular}


intolerance. According to the concept of two compartmental systems for insulin release in the $\beta$-cell (Porte and Pupo, 1969), there exists a small storage pool which responds to rapid changes in blood glucose, and a larger pool responding to a prolonged stimuli. The 'rapid' pool is considered to control the rate of peripheral glucose utilization (Lerner and Porte, 1971), while the second pool represents the function of pancreatic reserve. The positive insulin response to glucagon in the children described by us may show that the 'rapid' pool is intact, therefore explaining the lack of glucose intolerance. A relatively low glucagon response to intravenous arginine found in these children may also explain the relative insulin sensitivity (Josefsberg et al., 1974).

Further studies are required to determine whether the difference in response between glucose and glucagon of the $\beta$-cells in some patients with constitutional growth retardation is due to a cell receptor alteration.

All the children tested showed a rise in plasma growth hormone after the glucagon injection. The pattern of the response was not uniform, and the time of the appearance of the peak levels was variable, as reported by others (British Medical Journal, 1973). This pattern of response excludes a primary role of growth hormone in the insulin response.

M.K. was supported by the Israel Ministry of Health Grant no. M.Ch. 133. Z. L. is established Investigator of the Chief Scientist's Bureau Ministry of Health.

\section{REFERENCES}

British Medical fournal (1973). Glucagon and growth hormone, 1 , 188.

Chiumello, G., Del Guercio, M. J., and Bidone, G. (1968). Effect of glucagon and tolbutamide on plasma insulin levels in children with ketoacidosis. Diabetes, 17, 133.

Devrim, S., and Recant, L. (1966). Effect of glucagon on insulin release in vitro. Lancet, $2,1227$.

Hales, C. N., and Randle, R. J. (1963). Immunoassay of insulin with insulin antibody precipitate. Biochemical fournal, 88, 137.

Josefsberg, Z., Laron, Z., Doron, M., Karp, M., and Weissman, I. (1974). Plasma glucagon response to arginine infusion in children and adolescents with constitutional (familial) short stature. Fournal of Pediatrics, 85, 437.

Karp, M., Laron, Z., and Doron, M. (1973). Insulin secretion in children with constitutional familial short stature. Fournal of Pediatrics, 83, 241.

Laron, Z. (1968). Somatic growth in children from Israel. Proceedings of the 12th International Congress on Pediatrics, Mexico City, Vol. 1, p. 770.

Laron, Z., and Mannheimer, S. (1966). Measurements of human growth hormone. Israel fournal of Medical Sciences, 2, 115.

Laron, Z., Karp, M., Pertzelan, A., and Kauli, R. (1972). Insulin, growth and growth hormone. Israel fournal of Medical Sciences, 8, 440.

Lerner, R. L., and Porte, D., Jr. (1971). Relationship between intravenous glucose loads, insulin responses and glucose disappearance rate. Fournal of Clinical Endocrinology and Metabolism, 33, 409.

Porte, D., Jr., and Pupo, A. A. (1969). Insulin responses to glucose: evidence for a two pool system in man. Fournal of Clinical Investigation, 48, 2309.

Samols, E., Marri, G., and Marks, V. (1965). Promoticn of insulin secretion by glucagon. Lancet 2,415 .

Tanner, J. M., Whitehouse, R. H., and Takaishi, M. (1966). Standards from birth to maturity for height, weight, height velocity, and weight velocity. Archives of Disease in Childhood, 41, 454.

Weber, B. (1975). Glucagon induced insulin secretion in diabetic children. The Various Faces of Diabetes in Fuveniles, Modern Problems in Pediatrics, Vol. 12, p. 134. Ed. by Z. Laron and M. Karp. Karger, Basel and New York.

Correspondence to Professor Z. Laron, Institute of Paediatric and Adolescent Endocrinology, Beilinson Hospital, Petach Tikva, Israel. 